\title{
Copper-Based Catalysts for Selective Hydrogenation of Acetylene Derived from $\mathrm{Cu}(\mathrm{OH})_{2}$
}

\author{
Chenyang Lu, Aonan Zeng, Yao Wang,* and Anjie Wang*
}

Cite This: ACS Omega 2021, 6, 3363-3371

Read Online

ABSTRACT: Replacing precious metals with cheap metals in catalysts is a topic of interest in both industry and academia but challenging. Here, a selective hydrogenation catalyst was prepared by thermal treatment of $\mathrm{Cu}(\mathrm{OH})_{2}$ nanowires with acetylene-containing gas at $120{ }^{\circ} \mathrm{C}$ followed by hydrogen reduction at $150{ }^{\circ} \mathrm{C}$. The characterization by means of transmission

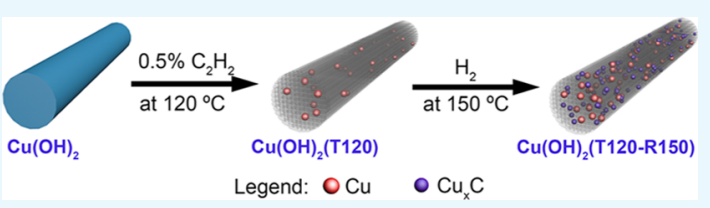
electron microscopy observation, $\mathrm{X}$-ray diffraction, and X-ray photoelectron spectroscopy revealed that two crystallites were present in the resultant catalyst. One of the crystal phases was metal $\mathrm{Cu}$, whereas the other crystal phase was ascribed to an interstitial copper carbide $\left(\mathrm{Cu}_{x} \mathrm{C}\right)$ phase. The reduction of freshly prepared copper (II) acetylide $\left(\mathrm{CuC}_{2}\right)$ at $150{ }^{\circ} \mathrm{C}$ also afforded the formation of $\mathrm{Cu}$ and $\mathrm{Cu}_{x} \mathrm{C}$ crystallites, indicating that $\mathrm{CuC}_{2}$ was the precursor or an intermediate in the formation of $\mathrm{Cu}_{x} \mathrm{C}$. The prepared catalysts consisting of $\mathrm{Cu}$ and $\mathrm{Cu}_{x} \mathrm{C}$ exhibited a considerably high hydrogenation activity at low temperatures in the selective hydrogenation of acetylene in the ethylene stream. In the presence of a large excess of ethylene, acetylene was completely converted at $110{ }^{\circ} \mathrm{C}$ and atmospheric pressure with an ethane selectivity of $<15 \%$, and the conversion and selectivity were constant in a $260 \mathrm{~h}$ run.

\section{INTRODUCTION}

Ethylene is mainly used for the production of polyethylene, the most widely used plastic. Ethylene feedstocks produced by steam cracking and alkane dehydrogenation always contain $0.5-2 \%$ acetylene, which is poisonous to the downstream polymerization catalysts and degrades the quality of polyethylene. ${ }^{1-3}$ Therefore, the amount of acetylene in polymergrade ethylene must be reduced to an acceptable level $(<5$ ppm). ${ }^{4,5}$ An industrially used method of removing acetylene in the ethylene stream is by the selective hydrogenation of acetylene to ethylene. ${ }^{5-7}$ Supported Pd catalysts promoted with $\mathrm{Ag}$ are commonly used in the petrochemical industry. ${ }^{8-12}$ However, there is room for improving the conventional catalysts in terms of cost and product selectivity.

Design of noble metal-free catalysts from base metals with high hydrogenation activity and ethylene selectivity offers an effective way for removing the trace acetylene from ethylene. Among the base metals, Ni-based, ${ }^{13-19} \mathrm{Cu}$-based, ${ }^{20-24}$ and Febased $^{25,26}$ catalysts have been investigated for the selective hydrogenation of acetylene. Remarkably, some of them showed higher selectivity to ethylene than the Pd-based catalysts. For example, a high alkene selectivity is readily achieved in alkyne hydrogenation over Cu-based catalysts. ${ }^{27-29}$ Nevertheless, higher reaction temperatures $\left(>150{ }^{\circ} \mathrm{C}\right)$ are often required because of the lower ability of hydrogen dissociation for the base-metal catalysts. A high reaction temperature often leads to enhanced oligomerization of acetylene, and the produced green oil fouls the catalyst surface and deactivates the catalyst. $^{30}$ As a result, lowering the reaction temperature is critical to improve the catalytic performance of base-metal catalysts. Kyriakou et al. ${ }^{31}$ reported that isolated Pd atoms on the $\mathrm{Cu}$ surface decreased the energy barrier of hydrogen uptake and desorption on the $\mathrm{Cu}$ surface. The $\mathrm{H}$ atoms dissociated on isolated $\mathrm{Pd}$ spilt over onto the $\mathrm{Cu}$ surface and facilitated the selective hydrogenation of acetylene, with improved selectivity to ethylene at lower temperatures. McCue et al. investigated the catalytic performance of a $\mathrm{Cu}$ / $\mathrm{Al}_{2} \mathrm{O}_{3}$ catalyst modified by different amounts of $\mathrm{Pd}^{32}$ They found that the optimal catalyst combined the properties of both $\mathrm{Cu}$ and $\mathrm{Pd}$ so as to achieve high ethylene selectivity with high activity at low reaction temperatures. The high hydrogenation activity was attributed to the $\mathrm{H}$ spillover from the $\mathrm{Pd}$ surface to the $\mathrm{Cu}$ surface.

In our previous study, a $\mathrm{Cu}_{2} \mathrm{O}$-derived catalyst displayed much higher activity than the $\mathrm{Cu}$ catalyst in acetylene selective hydrogenation with excess ethylene. ${ }^{33}$ The $\mathrm{Cu}_{2} \mathrm{O}$-derived catalyst was in a core-shell structure, with the $\mathrm{Cu}$ core covered by a porous carbon shell in which $\mathrm{Cu}$ and copper carbide $\left(\mathrm{Cu}_{x} \mathrm{C}\right)$ particles were highly dispersed. The density functional theory (DFT) calculation results revealed that $\mathrm{Cu}_{x} \mathrm{C}$ was corresponding to $\mathrm{Cu}_{3} \mathrm{C}$ with a structure of rhombohedracentered hexagonal, and the dissociation energy of $\mathrm{H}_{2}$ on $\mathrm{Cu}_{3} \mathrm{C}(0001)$ is extraordinary lower than that on $\mathrm{Cu}(111)$. Meanwhile, the barriers of acetylene hydrogenation to

Received: December 2, 2020

Accepted: December 24, 2020

Published: January 17, 2021 

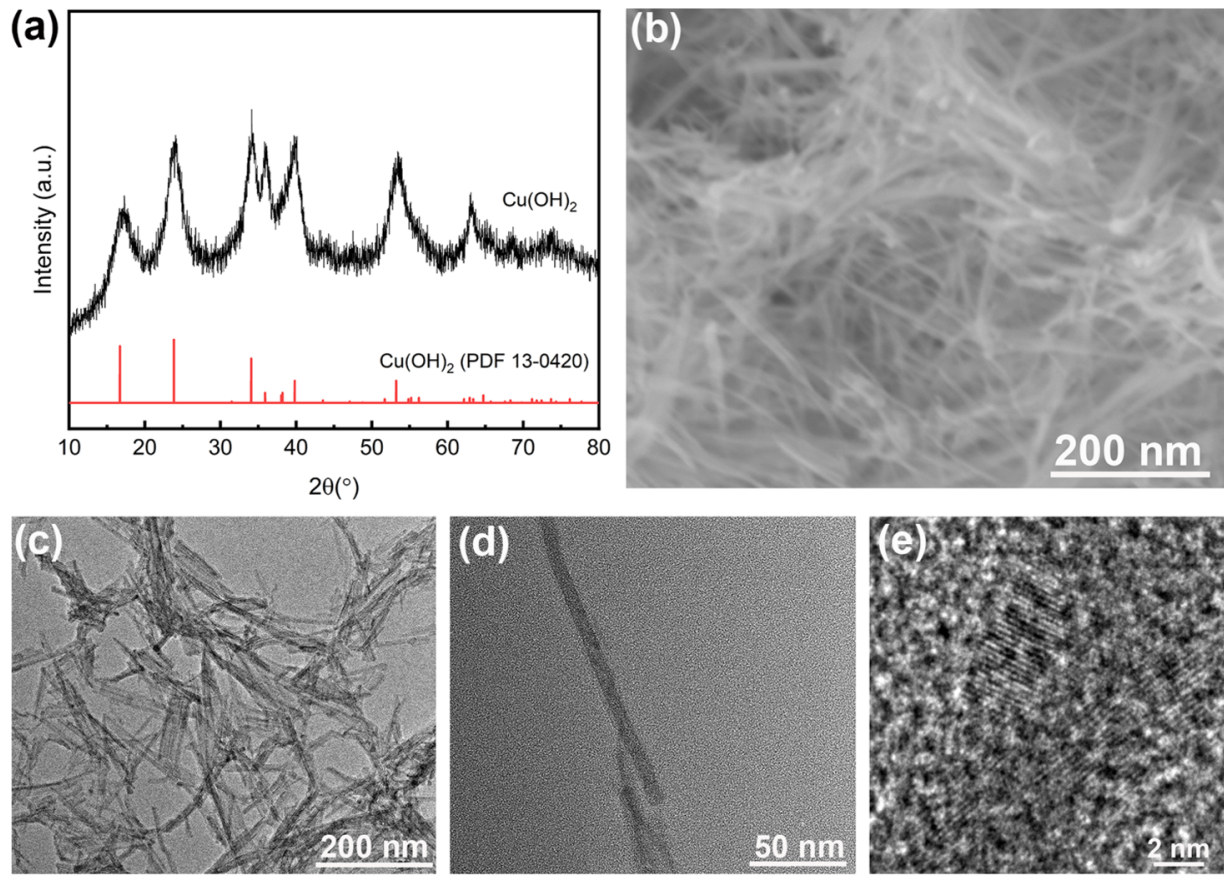

Figure 1. (a) XRD pattern, (b) SEM image, (c,d) TEM images, and (e) HRTEM image of the synthesized $\mathrm{Cu}(\mathrm{OH})_{2}$ nanowires.

vinylidene and then to ethylene over $\mathrm{Cu}_{3} \mathrm{C}(0001)$ were higher than that on $\mathrm{Cu}(111)$. Therefore, $\mathrm{Cu}_{x} \mathrm{C}$ served as the sites for $\mathrm{H}_{2}$ adsorption and dissociation, and the $\mathrm{Cu}$ phase was the main site for acetylene hydrogenation. In the present study, $\mathrm{Cu}(\mathrm{OH})_{2}$ was used to prepare the acetylene selective hydrogenation catalyst using the same method. The prepared catalysts were characterized and tested in the selective hydrogenation of acetylene in the presence of a large excess of ethylene.

\section{RESULTS AND DISCUSSION}

2.1. Catalyst Characterization. Figure 1a shows the $\mathrm{X}$-ray diffraction (XRD) pattern of the synthesized $\mathrm{Cu}(\mathrm{OH})_{2}$. It indicates that pure $\mathrm{Cu}(\mathrm{OH})_{2}$ crystal phase was obtained. The scanning electron microscopy (SEM) image of $\mathrm{Cu}(\mathrm{OH})_{2}$ (Figure $1 \mathrm{~b}$ ) demonstrated that $\mathrm{Cu}(\mathrm{OH})_{2}$ was in bundles of nanowires. The transmission electron microscopy (TEM) observation indicated that the average diameter of the nanowires was $\sim 15 \mathrm{~nm}$ (Figure 1c,d). The high-resolution TEM (HRTEM) image indicated the presence of $\mathrm{Cu}(\mathrm{OH})_{2}$ polycrystallites in the nanowires (Figure 1e).

When $\mathrm{Cu}(\mathrm{OH})_{2}$ was treated with an acetylene-containing gas $\left(0.50 \% \mathrm{C}_{2} \mathrm{H}_{2}\right.$ and $\left.99.50 \% \mathrm{Ar}\right)$ at $120{ }^{\circ} \mathrm{C}$ for $2 \mathrm{~h}$, the color changed from blue to black. As shown in the SEM image of the obtained material $\left[\mathrm{Cu}(\mathrm{OH})_{2}(\mathrm{~T} 120)\right]$ (Figure 2a), the thermal treatment with acetylene-containing gas led to a partial fracture of the nanowires, and the average diameter of the nanowires was increased probably due to carbon deposition on the external surface. After $\mathrm{Cu}(\mathrm{OH})_{2}(\mathrm{~T} 120)$ was subsequently reduced in $\mathrm{H}_{2}$ at $150{ }^{\circ} \mathrm{C}$ for $3 \mathrm{~h}$, the morphology of the obtain catalyst $\mathrm{Cu}(\mathrm{OH})_{2}(\mathrm{~T} 120-\mathrm{R} 150)$ (Figure 2b) did not change significantly.

The HRTEM image of $\mathrm{Cu}(\mathrm{OH})_{2}(\mathrm{~T} 120-\mathrm{R} 150)$ (Figure 2c) revealed the presence of two kinds of crystallites with different lattice spacings. The lattice spacing of $0.181 \mathrm{~nm}$ corresponded to the (200) plane of $\mathrm{Cu}$ crystallites, whereas the other one $(0.238 \mathrm{~nm})$ was different from those of $\mathrm{Cu}, \mathrm{CuO}$, and
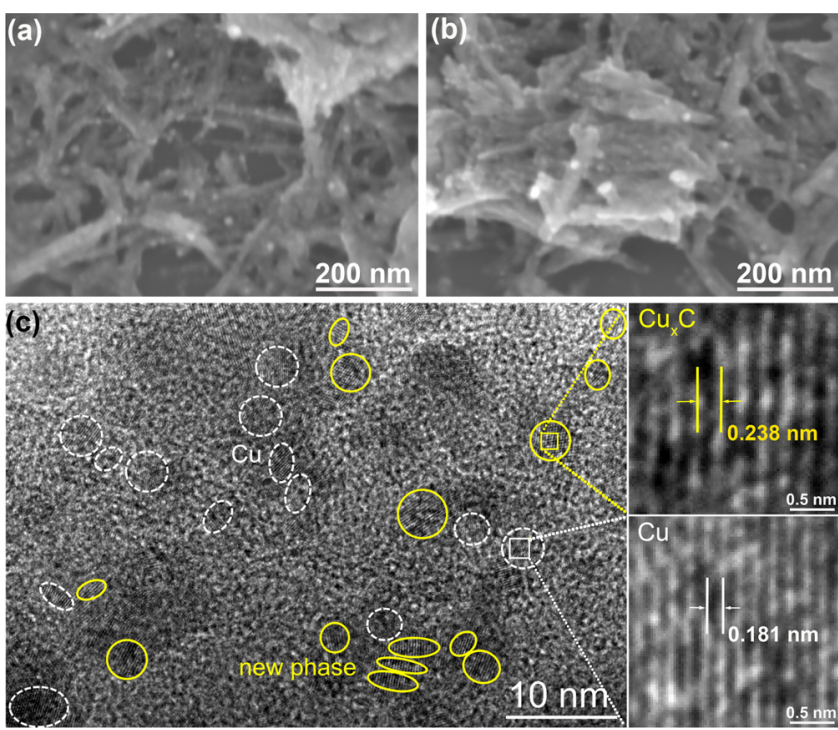

Figure 2. SEM images of (a) $\mathrm{Cu}(\mathrm{OH})_{2}(\mathrm{~T} 120)$ and (b) $\mathrm{Cu}$ $(\mathrm{OH})_{2}(\mathrm{~T} 120-\mathrm{R} 150)$. (c) HRTEM image of $\mathrm{Cu}(\mathrm{OH})_{2}(\mathrm{~T} 120-\mathrm{R} 150)$.

$\mathrm{Cu}(\mathrm{OH})_{2}$ and was consistent with the lattice spacing of the $\mathrm{Cu}_{3} \mathrm{C}(0001)$ plane determined by DFT calculation in the previous $\mathrm{Cu}_{2} \mathrm{O}$-derived catalyst. ${ }^{33}$ Figure 3 a presents the XRD pattern of $\mathrm{Cu}(\mathrm{OH})_{2}(\mathrm{~T} 120-\mathrm{R} 150)$. The intense peaks at $2 \theta=$ $43.3,50.4$, and $74.1^{\circ}$ were ascribed to the (111), (200), and (220) planes of metal $\mathrm{Cu}$ (PDF 04-0836). The diffraction peak at $2 \theta=37.1^{\circ}$ did not fit to the patterns of $\mathrm{Cu}(\mathrm{OH})_{2}, \mathrm{Cu}_{2} \mathrm{O}$ and $\mathrm{CuO}$ but was identical to that of the interstitial copper carbide $\left(\mathrm{Cu}_{x} \mathrm{C}\right)$ in the previous report. ${ }^{33}$

Figure $3 \mathrm{~b}-\mathrm{d}$ illustrates the $\mathrm{X}$-ray photoelectron spectroscopy (XPS) spectra of $\mathrm{Cu}(\mathrm{OH})_{2}(\mathrm{~T} 120-\mathrm{R} 150)$ in comparison with the metal $\mathrm{Cu}$. In the $\mathrm{Cu} 2 \mathrm{p}_{2 / 3}$ region (Figure $3 \mathrm{~b}$ ), the absence of the peak at 933.2-934.6 eV and its satellite peak at around $945 \mathrm{eV}$ indicated that no $\mathrm{Cu}^{2+}$ species were present in $\mathrm{Cu}(\mathrm{OH})_{2}(\mathrm{~T} 120-\mathrm{R} 150)$ and in the $\mathrm{Cu}$ catalyst, ${ }^{21,34}$ suggesting 

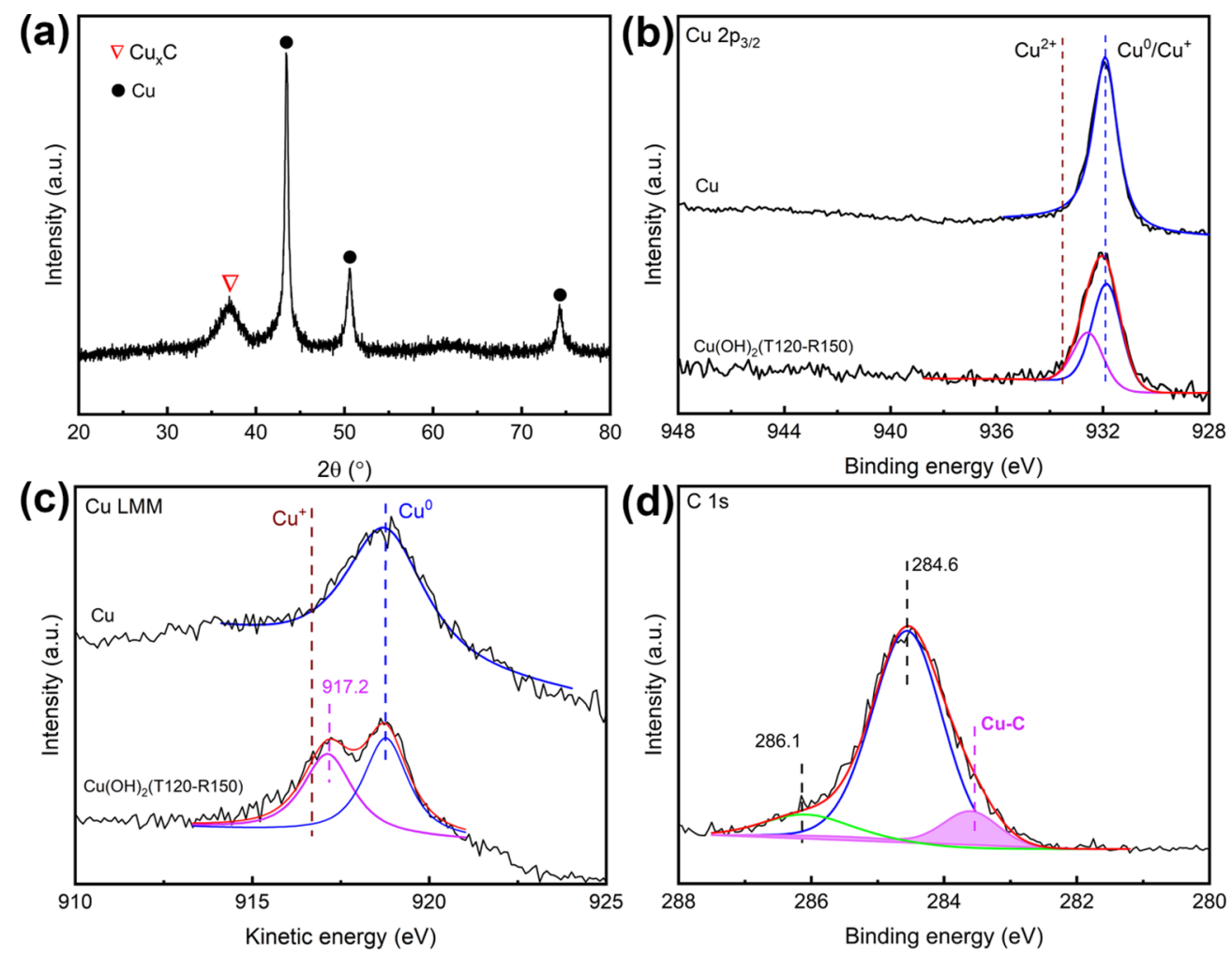

Figure 3. (a) XRD pattern of $\mathrm{Cu}(\mathrm{OH})_{2}(\mathrm{~T} 120-\mathrm{R} 150)$. (b) $\mathrm{Cu} 2 \mathrm{p}_{3 / 2}$ and (c) Cu LMM XPS spectra of $\mathrm{Cu}(\mathrm{OH})_{2}(\mathrm{~T} 120-\mathrm{R} 150)$ and the Cu catalyst. (d) C 1s spectra of $\mathrm{Cu}(\mathrm{OH})_{2}(\mathrm{~T} 120-\mathrm{R} 150)$.

that $\mathrm{Cu}^{2+}$ species had been reduced in the hydrogenation at $150{ }^{\circ} \mathrm{C}$. The main peak in the $\mathrm{Cu} 2 \mathrm{p}_{3 / 2}$ spectrum of $\mathrm{Cu}(\mathrm{OH})_{2}(\mathrm{~T} 120-\mathrm{R} 150)$ could be deconvoluted to a peak characteristic of metal copper and a shoulder peak at $932.8 \mathrm{eV}$ located between $\mathrm{Cu}^{2+}$ and $\mathrm{Cu}^{0} / \mathrm{Cu}^{+}$. It was due to the formation of $\mathrm{Cu}-\mathrm{C}$ in $\mathrm{Cu}_{x} \mathrm{C} .^{21}$ A shift to higher binding energy suggests the transfer of electron density from copper to carbon, resulting in a partial positive charge $\left(\delta^{+}\right)$of the new $\mathrm{Cu}$ species in $\mathrm{Cu}_{x} \mathrm{C}^{35}$ In the $\mathrm{Cu}$ LMM spectrum of $\mathrm{Cu}$ $(\mathrm{OH})_{2}(\mathrm{~T} 120-\mathrm{R} 150)$ (Figure 3c), two peaks at 917.2 and $918.7 \mathrm{eV}$ were observed, whereas there was only one peak at $918.7 \mathrm{eV}$ in the $\mathrm{Cu}$ catalyst. The peak at $918.7 \mathrm{eV}$ was attributed to $\mathrm{Cu}^{0}$ species, ${ }^{36}$ whereas the kinetic energy (KE) at $917.2 \mathrm{eV}$ was different from that of $\mathrm{Cu}^{+}(\mathrm{KE} 916.8 \mathrm{eV})$. Because $\mathrm{Cu}^{2+}$ was absent (Figure $3 \mathrm{~b}$ ), the new peak at $\mathrm{KE}$ of $917.2 \mathrm{eV}$ was tentatively assigned to the $\mathrm{Cu}-\mathrm{C}$ bond in $\mathrm{Cu}_{x} \mathrm{C}$. In the $\mathrm{C} 1 \mathrm{~s}$ region (Figure $3 \mathrm{~d}$ ), the large peak at $284.6 \mathrm{eV}$ was attributed to the $\mathrm{C}-\mathrm{C}$ bond, ${ }^{39}$ whereas the shoulder at 286.1 $\mathrm{eV}$ corresponded to the $\mathrm{C}-\mathrm{OH}$ species. ${ }^{37}$ The shoulder at $283.6 \mathrm{eV}$ was attributable to the interstitial metal carbide carbon of $\mathrm{Cu}_{x} \mathrm{C} .^{33,38} \mathrm{Kim}$ et al. also confirmed that the simultaneous appearance of the two peaks at $932.8 \mathrm{eV}$ in the $\mathrm{Cu} 2 \mathrm{p}_{2 / 3}$ spectrum and $283.6 \mathrm{eV}$ in the $\mathrm{C} 1$ s spectrum was due to the formation of copper carbide. ${ }^{39}$ Therefore, it suggests that the interstitial copper carbide $\left(\mathrm{Cu}_{x} \mathrm{C}\right)$ was present in the $\mathrm{Cu}(\mathrm{OH})_{2}$-derived catalyst.

In the Raman spectrum of $\mathrm{Cu}(\mathrm{OH})_{2}(\mathrm{~T} 120)$ (Figure $\mathrm{S} 1$ ), the two peaks at $\sim 1570$ and $\sim 1370 \mathrm{~cm}^{-1}$ corresponding to the $G$ band and $D$ band of carbon, which are related to the structural order ( $\mathrm{sp}^{2}$ carbons) and the imperfection present in the carbon lattice, ${ }^{40}$ were observed, suggesting that carbon was formed in the acetylene treatment step, and the presence of $\mathrm{G}$ band and $\mathrm{D}$ band in $\mathrm{Cu}(\mathrm{OH})_{2}(\mathrm{~T} 120-\mathrm{R} 150)$ indicated that the formed carbon was stable in $\mathrm{H}_{2}$ reduction at $150{ }^{\circ} \mathrm{C}$. The Brunauer-Emmett-Teller (BET) specific surface areas of $\mathrm{Cu}(\mathrm{OH})_{2}, \quad \mathrm{Cu}(\mathrm{OH})_{2}(\mathrm{~T} 120)$, and $\mathrm{Cu}(\mathrm{OH})_{2}(\mathrm{~T} 120-\mathrm{R} 150)$ (Figure S2) increased from 70 to 103 and to $162 \mathrm{~m}^{2} / \mathrm{g}$. The increased surface area may suggest that the carbon material, in which $\mathrm{Cu}_{x} \mathrm{C}$ and $\mathrm{Cu}$ particles were embedded, was porous in $\mathrm{Cu}(\mathrm{OH})_{2}(\mathrm{~T} 120)$ and $\mathrm{Cu}(\mathrm{OH})_{2}(\mathrm{~T} 120-\mathrm{R} 150)$.

In our previous study, it was found that the $\mathrm{Cu}_{x} \mathrm{C}$ phase was obtained by reducing copper (I) acetylide $\left(\mathrm{Cu}_{2} \mathrm{C}_{2}\right)$ in $\mathrm{H}_{2}{ }^{33}$ Similarly, it is proposed that $\mathrm{Cu}_{x} \mathrm{C}$ in $\mathrm{Cu}(\mathrm{OH})_{2}$-derived catalyst originated from copper (II) acetylide $\left(\mathrm{CuC}_{2}\right)$ : (1) $\mathrm{Cu}(\mathrm{OH})_{2}$ reacts with acetylene to afford $\mathrm{CuC}_{2}$ at $120{ }^{\circ} \mathrm{C}$; (2) $\mathrm{CuC}_{2}$ is partially reduced in hydrogen at $150{ }^{\circ} \mathrm{C}$ to form $\mathrm{Cu}_{x} \mathrm{C}$. When $\mathrm{Cu}(\mathrm{OH})_{2}$ was treated with acetylene-containing gas at $120{ }^{\circ} \mathrm{C}$, water drops was observed downstream on the inner wall of the quartz tube, and the color of the catalyst bed changed from blue to black. These phenomena indicated that $\mathrm{Cu}(\mathrm{OH})_{2}$ reacted with acetylene readily to produce $\mathrm{CuC}_{2}{ }^{41}$ Because $\mathrm{CuC}_{2}$ is highly unstable, it partially decomposed to $\mathrm{Cu}$ particles and carbonaceous materials as a parallel reaction in the thermal treatment at $120{ }^{\circ} \mathrm{C}$ and in the subsequent hydrogen reduction at $150{ }^{\circ} \mathrm{C}$. The carbon deposition on the external surface of the nanowires might result from the decomposition of the in situ generated $\mathrm{CuC}_{2}{ }^{42}$

In order to elucidate that the formation of $\mathrm{Cu}_{x} \mathrm{C}$ was from $\mathrm{CuC}_{2}$ by hydrogen reduction, bulk $\mathrm{CuC}_{2}$ (CAUTION: dry bulk $\mathrm{CuC}_{2}$ is explosive) was synthesized by bubbling acetylene-containing gas into a $\mathrm{Cu}\left(\mathrm{NO}_{3}\right)_{2}$ ammonia solution. The obtained $\mathrm{CuC}_{2}$ was treated in two different atmospheres at $150{ }^{\circ} \mathrm{C}$ for $3 \mathrm{~h}$. The material obtained after thermal treatment in hydrogen was denoted as $\mathrm{CuC}_{2} @ 150-\mathrm{H}_{2}$ and that in vacuum as $\mathrm{CuC}_{2} @ 150$-vacuum. The HRTEM observation of $\mathrm{CuC}_{2} @ 150-\mathrm{H}_{2}$ indicated the presence of $\mathrm{Cu}_{x} \mathrm{C}$ and $\mathrm{Cu}$ 

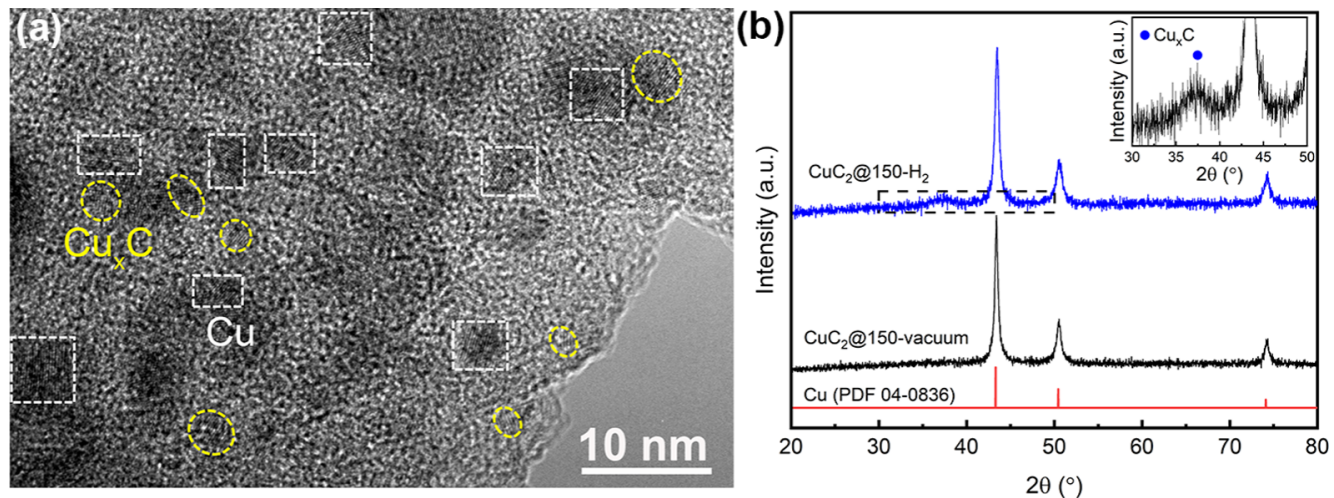

Figure 4. (a) HRTEM image of the material obtained by reducing bulk $\mathrm{CuC}_{2}$ in hydrogen at $150{ }^{\circ} \mathrm{C}$ for $3 \mathrm{~h}$. (b) $\mathrm{XRD}$ patterns of $\mathrm{CuC} \mathrm{C}_{2} @ 150-\mathrm{H}_{2}$ and $\mathrm{CuC}_{2} @ 150$-vacuum.
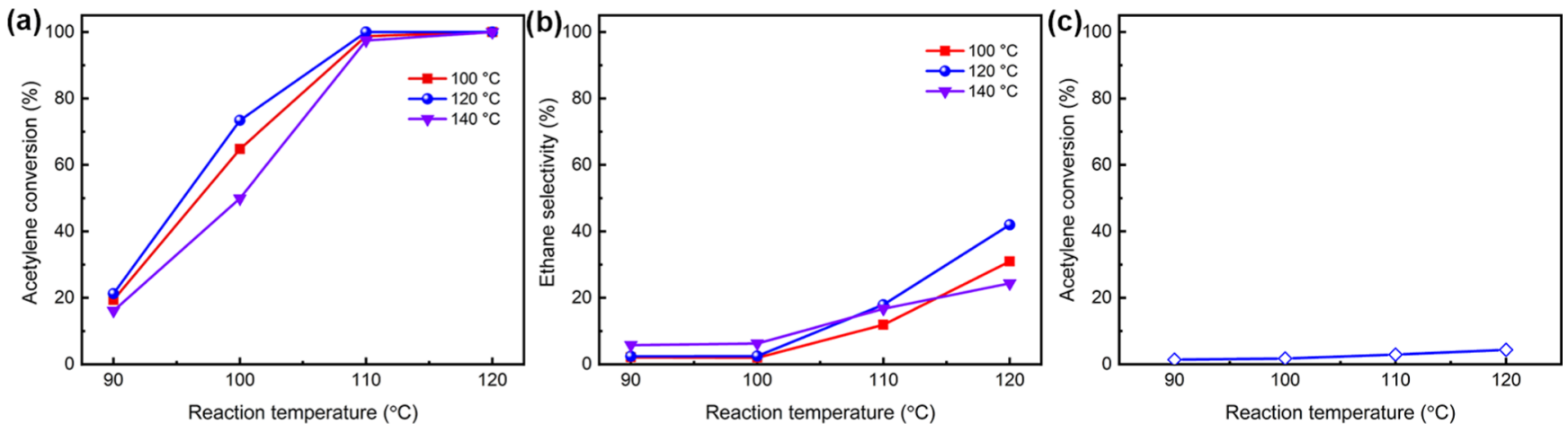

Figure 5. (a) Acetylene conversion and (b) ethane selectivity as a function of reaction temperature over the materials obtained from $\mathrm{Cu}(\mathrm{OH})_{2}$ after thermal treatment at various temperatures followed by hydrogen reduction at $150{ }^{\circ} \mathrm{C}$. (c) Acetylene conversion as a function of the reaction temperature over the $\mathrm{Cu}$ catalyst.
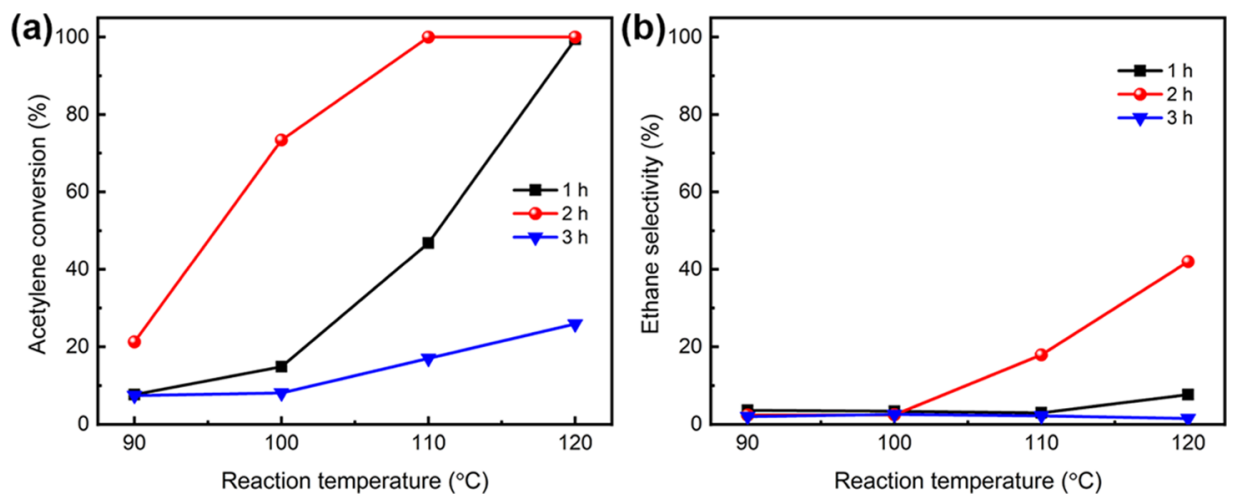

Figure 6. (a) Acetylene conversion and (b) ethane selectivity as a function of the reaction temperature over the catalysts derived from $\mathrm{Cu}(\mathrm{OH})_{2}$ treated for different times at $120^{\circ} \mathrm{C}$ followed by hydrogen reduction at $150{ }^{\circ} \mathrm{C}$.

crystallites, which were highly dispersed in the carbonaceous matrix (Figure 4a). The XPS characterization of $\mathrm{CuC}_{2} @ 150$ $\mathrm{H}_{2}$ (Figure S3) also suggested the presence of the $\mathrm{Cu}-\mathrm{C}$ bond in $\mathrm{Cu}_{x} \mathrm{C}$. In addition, the XRD pattern of $\mathrm{CuC}_{2} @ 150-\mathrm{H}_{2}$ revealed the presence of both $\mathrm{Cu}_{x} \mathrm{C}$ and $\mathrm{Cu}$ crystal phases as well (Figure $4 \mathrm{~b}$ ). As a result, it is evident that $\mathrm{Cu}_{x} \mathrm{C}$ was derived from $\mathrm{CuC}_{2}$ by hydrogen reduction at $150{ }^{\circ} \mathrm{C}$. In contrast, the three diffraction peaks at $2 \theta=43.3,50.4$, and $74.1^{\circ}$ in the XRD pattern of $\mathrm{CuC}_{2} @ 150$-vacuum suggests that the thermal decomposition of $\mathrm{CuC}_{2}$ led to the formation of $\mathrm{Cu}$ particles and carbonaceous materials. ${ }^{42}$ The BET specific surface areas of $\mathrm{CuC}_{2} @ 150-\mathrm{H}_{2}$ and $\mathrm{CuC}_{2} @ 150$-vacuum were
146 and $165 \mathrm{~m}^{2} / \mathrm{g}$ (Figure S4), respectively, comparable to that of $\mathrm{Cu}(\mathrm{OH})_{2}(\mathrm{~T} 120-\mathrm{R} 150)$.

2.2. Catalytic Performance. In our previous investigation on the $\mathrm{Cu}_{2} \mathrm{O}$-derived catalyst, it was found that the acetylene treatment conditions and subsequent hydrogenation conditions significantly affected the performance of the prepared catalysts in the selective hydrogenation of acetylene.

Figure 5 shows the effect of thermal treatment temperature on the performance of the catalyst prepared by subsequent hydrogen reduction at $150{ }^{\circ} \mathrm{C}$. All three catalysts showed significantly high hydrogenation activity with low ethane selectivity. Above $110{ }^{\circ} \mathrm{C}$, acetylene in the ethylene stream was completely removed with ethane selectivity below $40 \%$. In 

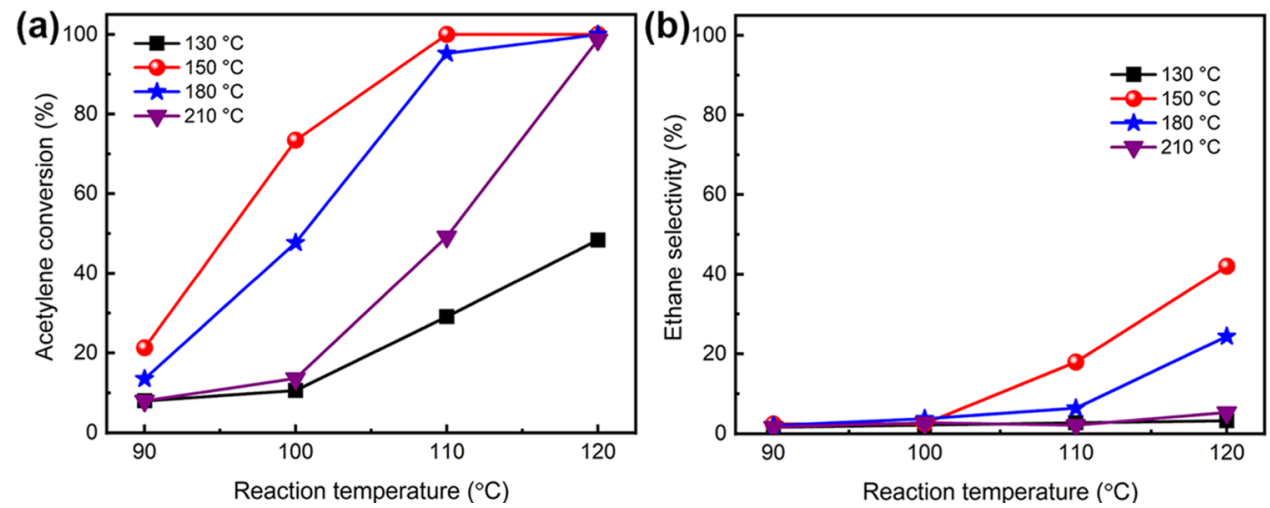

Figure 7. (a) Acetylene conversion and (b) ethane selectivity as a function of the reaction temperature over the catalysts derived from $\mathrm{Cu}(\mathrm{OH})_{2}$ treated at $120{ }^{\circ} \mathrm{C}$ and reduced at different temperatures.
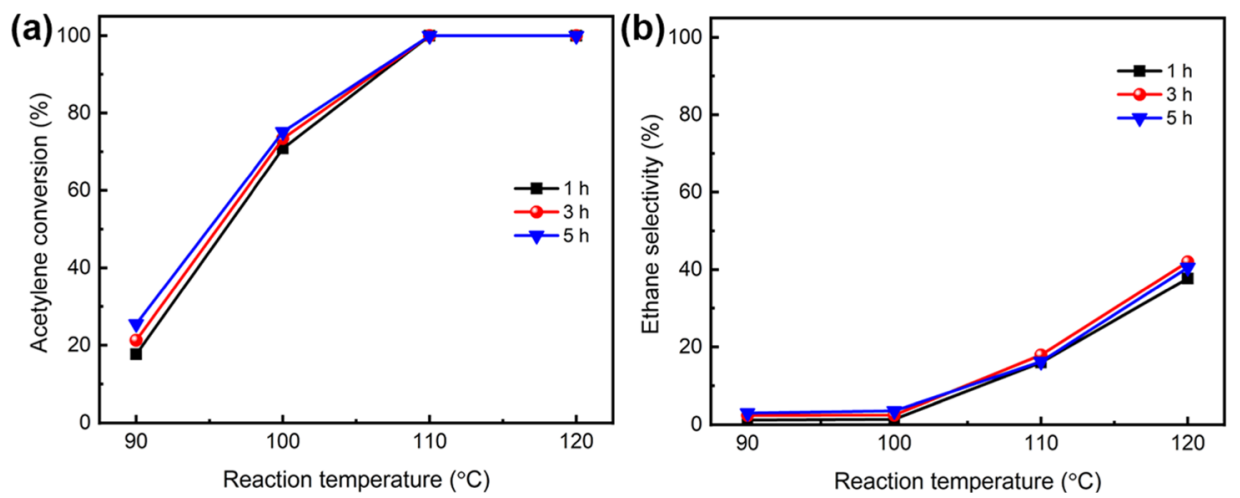

Figure 8. (a) Acetylene conversion and (b) ethane selectivity as a function of the reaction temperature over the catalysts derived from $\mathrm{Cu}(\mathrm{OH})_{2}$ treated at $120{ }^{\circ} \mathrm{C}$ followed by hydrogen reduction at $150{ }^{\circ} \mathrm{C}$ for different times.

contrast, acetylene conversion over the $\mathrm{Cu}$ catalyst, which was obtained from the same precursor $\left[\mathrm{Cu}(\mathrm{OH})_{2}\right]$ by hydrogen reduction at $400{ }^{\circ} \mathrm{C}$ for $5 \mathrm{~h}$, was extremely low in the temperature range of $90-120^{\circ} \mathrm{C}$ (Figure $5 \mathrm{c}$ ). At $100{ }^{\circ} \mathrm{C}$, the catalyst treated at $120{ }^{\circ} \mathrm{C}\left[\mathrm{Cu}(\mathrm{OH})_{2}(\mathrm{~T} 120-\mathrm{R} 150)\right]$ exhibited the highest activity. The thermal treatment of $\mathrm{Cu}(\mathrm{OH})_{2}$ with acetylene leads to the formation of copper (II) acetylide $\left(\mathrm{CuC}_{2}\right) \cdot{ }^{43}$ Since $\mathrm{CuC}_{2}$ is thermally unstable, it decomposes to yield $\mathrm{Cu}$ metal and amorphous carbon. Thermogravimetric (TG)-differential scanning calorimetry (DSC) curve of the prepared $\mathrm{CuC}_{2}$ (Figure S5) indicates that a strong exothermic peak appeared around $130{ }^{\circ} \mathrm{C}$, suggesting that $\mathrm{CuC}_{2}$ decomposed markedly above $130{ }^{\circ} \mathrm{C}$. As a result, the formation of $\mathrm{CuC}_{2}$ involves a consecutive reaction: the formation of $\mathrm{CuC}_{2}$ and the simultaneous thermal decomposition of $\mathrm{CuC}_{2}$. Therefore, an optimal treatment temperature exists.

Figure 6 displays the effect of treatment time at $120{ }^{\circ} \mathrm{C}$ on the performance of the prepared catalysts in the selective hydrogenation of acetylene. It is indicated that the optimal treatment time was $2 \mathrm{~h}$. In the thermal treatment of $\mathrm{Cu}(\mathrm{OH})_{2}$ with acetylene, $\mathrm{CuC}_{2}$ acted like the desired product in a consecutive reaction, whose yield passed a maximum with increasing time. When treated for $3 \mathrm{~h}$, the catalytic activity dropped dramatically, suggesting that the thermal decomposition of $\mathrm{CuC}_{2}$ predominated after $2 \mathrm{~h}$.

The effective conversion of the in situ generated $\mathrm{CuC}_{2}$ to $\mathrm{Cu}_{x} \mathrm{C}$ particles plays a determining role in the hydrogenation activity of the resultant catalyst. In the subsequent hydrogen reduction at higher temperatures, two parallel reactions, the reduction and the decomposition of $\mathrm{CuC}_{2}$, take place competitively. At optimal thermal treatment conditions (120 ${ }^{\circ} \mathrm{C}$ for $2 \mathrm{~h}$ ), the effect of reduction temperature on the performance of the catalyst was then investigated. Figure 7 shows the effect of the reduction temperature on acetylene conversion and ethane selectivity of the prepared catalysts. Reduction at $150{ }^{\circ} \mathrm{C}$ for $3 \mathrm{~h}$ resulted in the highest hydrogenation activity. When $\mathrm{Cu}(\mathrm{OH})_{2}(\mathrm{~T} 120)$ was reduced at $130{ }^{\circ} \mathrm{C}$ for $3 \mathrm{~h}$, the acetylene conversion on the obtained catalyst was much lower, which might be attributable to the reduced production of $\mathrm{Cu}_{x} \mathrm{C}$, probably due to the low rate of $\mathrm{CuC}_{2}$ reduction. On the other hand, at higher temperatures (180 and $210{ }^{\circ} \mathrm{C}$ ), the enhanced thermal decomposition of $\mathrm{CuC}_{2}$ might lead to reduced production of $\mathrm{Cu}_{x} \mathrm{C}$, lowering the catalytic activity.

Figure 8 presents the effect of reduction time at $150{ }^{\circ} \mathrm{C}$ on the acetylene hydrogenation performance of the resultant catalysts. It is indicated that the reduction time slightly affected the performance of the catalyst, probably because the reduction took place quickly at $150{ }^{\circ} \mathrm{C}$.

For practical application in removing the acetylene impurity from the ethylene product, there are many important factors which govern the performance and operation of the selective hydrogenation catalyst. Among them, the effect of hydrogen partial pressure and the catalyst stability are of paramount importance. In the industry, the Pd-based catalyst is sensitive to $\mathrm{H}_{2}$ partial pressure change, and therefore, the $\mathrm{H}_{2} / \mathrm{C}_{2} \mathrm{H}_{2}$ ratio is strictly controlled around $2 .{ }^{22}$ Lower $\mathrm{H}_{2}$ partial pressure leads to decreased acetylene conversion and increased formation of green oil. Higher $\mathrm{H}_{2}$ partial pressure results in overhydrogenation of ethylene in the feed and increases the 

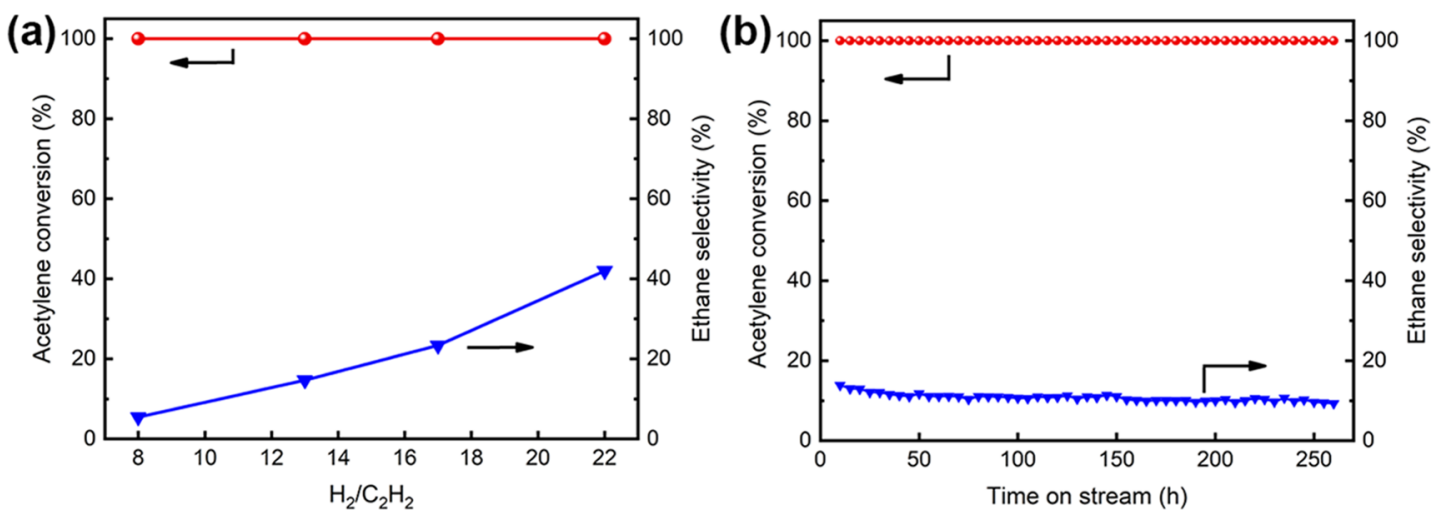

Figure 9. (a) Effect of $\mathrm{H}_{2} / \mathrm{C}_{2} \mathrm{H}_{2}$ ratio on acetylene conversion and ethane selectivity in acetylene hydrogenation over $\mathrm{Cu}(\mathrm{OH})_{2}(\mathrm{~T} 120-\mathrm{R} 150)$ at $120^{\circ} \mathrm{C}$ and atmospheric pressure. (b) Variation of acetylene conversion and ethane selectivity with time on stream in acetylene hydrogenation over $\mathrm{Cu}(\mathrm{OH})_{2}(\mathrm{~T} 120-\mathrm{R} 150)$ at $110{ }^{\circ} \mathrm{C}$.

risk of thermal runaway of the catalyst bed because of the high exothermicity of ethylene hydrogenation. As a result, a complicated computer-aided control system is frequently constructed to monitor the variation of acetylene concentration and promptly respond to the change, so as to operate the reactor safely without net ethylene loss. In addition, the stability of the catalyst is an important concern because acetylene is prone to producing polymer and oligomer that foul the catalyst.

The ratio of hydrogen to acetylene $\left(\mathrm{H}_{2} / \mathrm{C}_{2} \mathrm{H}_{2}\right)$ is strictly monitored in Pd-catalyzed selective hydrogenation for the removal of the acetylene impurity in the ethylene product in the industry. A high $\mathrm{H}_{2} / \mathrm{C}_{2} \mathrm{H}_{2}$ ratio often leads to the formation of an unselective palladium hydride phase and overhydrogenation to ethane, resulting in a net ethylene loss and increasing the risk of a thermal runaway due to the high exothermicity of ethylene hydrogenation. A low $\mathrm{H}_{2} / \mathrm{C}_{2} \mathrm{H}_{2}$ ratio decreases acetylene conversion and is favorable to the oligomerization of acetylene to produce green oil, leading to catalyst deactivation. Figure 9a displays the dependence of acetylene conversion and ethane selectivity on the $\mathrm{H}_{2} / \mathrm{C}_{2} \mathrm{H}_{2}$ ratio in the acetylene selective hydrogenation catalyzed by $\mathrm{Cu}(\mathrm{OH})_{2}(\mathrm{~T} 120-\mathrm{R} 150)$ at $120{ }^{\circ} \mathrm{C}$ and atmospheric pressure. In the range of $8-22$, complete acetylene conversion was obtained, and the ethane selectivity increased insignificantly with the $\mathrm{H}_{2} / \mathrm{C}_{2} \mathrm{H}_{2}$ ratio. Increasing the partial pressure of $\mathrm{H}_{2}$ favors the adsorption of $\mathrm{H}_{2}$ on the catalyst surface, leading to increased surface coverage and hydrogenation rate. Remarkably, the selectivity to undesired ethane did not change dramatically with the $\mathrm{H}_{2} / \mathrm{C}_{2} \mathrm{H}_{2}$ ratio, and less than $40 \%$ ethane selectivity was obtained at the $\mathrm{H}_{2} / \mathrm{C}_{2} \mathrm{H}_{2}$ ratio of 22 . Apparently, it is advantageous to operate the selective hydrogenation in a wide window of $\mathrm{H}_{2} / \mathrm{C}_{2} \mathrm{H}_{2}$ ratio with the complete removal of acetylene and without a net ethylene loss.

Figure $9 \mathrm{~b}$ illustrates the variation of acetylene conversion and ethane selectivity with time on stream in the acetylene selective hydrogenation catalyzed by $\mathrm{Cu}(\mathrm{OH})_{2}(\mathrm{~T} 120-\mathrm{R} 150)$ at $110{ }^{\circ} \mathrm{C}$ and atmospheric pressure. $\mathrm{Cu}(\mathrm{OH})_{2}(\mathrm{~T} 120-\mathrm{R} 150)$ showed constant acetylene conversion (100\%) and low ethane selectivity $(<15 \%)$ in the $260 \mathrm{~h}$ run. The Cu-based catalysts were reported to induce oligomerization and polymerization in acetylene hydrogenation at high temperatures. ${ }^{30}$ The resultant oligomers (also known as green oils) and polymer foul the surface of the catalysts, thus leading to fast deactivation. In contrast, $\mathrm{Cu}(\mathrm{OH})_{2}(\mathrm{~T} 120-\mathrm{R} 150)$ showed substantially high stability on the stream. The improved stability of $\mathrm{Cu}$ $(\mathrm{OH})_{2}(\mathrm{~T} 120-\mathrm{R} 150)$ might be attributed to the lowered reaction temperature and to the porous carbonaceous matrix, which may suppress the chain growth of linear hydrocarbons because of steric hindrance.

\section{CONCLUSIONS}

In summary, it was demonstrated that the interstitial copper carbide $\left(\mathrm{Cu}_{x} \mathrm{C}\right)$ phase with high hydrogenation activity was synthesized by thermal treatment of $\mathrm{Cu}(\mathrm{OH})_{2}$ with $\mathrm{C}_{2} \mathrm{H}_{2}$ at $120{ }^{\circ} \mathrm{C}$ followed by $\mathrm{H}_{2}$ reduction at $150{ }^{\circ} \mathrm{C}$. The resultant catalyst exhibited outstanding performance and stability in the selective hydrogenation of acetylene in ethylene stream. $\mathrm{Cu}_{x} \mathrm{C}$ and $\mathrm{Cu}$ particles in the porous carbonaceous matrix served as the catalytic sites for hydrogen dissociation and acetylene hydrogenation, respectively. It is experimentally evident that copper (II) acetylide $\left(\mathrm{CuC}_{2}\right)$ was the precursor or intermediate in the formation of the $\mathrm{Cu}_{x} \mathrm{C}$ crystal phase. The reduction of $\mathrm{CuC}_{2}$ afforded $\mathrm{Cu}_{x} \mathrm{C}$ crystallites, whereas the thermal decomposition of $\mathrm{CuC}_{2}$ led to the formation of $\mathrm{Cu}$ particles and carbonaceous material. $\mathrm{Cu}$ metal was highly selective, whereas the high hydrogenation activity of $\mathrm{Cu}_{x} \mathrm{C}$ enabled the effective hydrogenation of acetylene at low temperatures. The porous carbonaceous material might facilitate the diffusion of small molecules involved in the hydrogenation, whereas it might pose a steric hindrance to the chain growth of linear hydrocarbons. The prepared catalyst could be applied both in the front-end process and in the backend process in removing the acetylene impurity in ethylene because the selectivity of ethane does not change markedly with hydrogen partial pressure in a wide range.

\section{EXPERIMENTAL SECTION}

4.1. Materials. $\mathrm{Cu}\left(\mathrm{NO}_{3}\right)_{2} \cdot 3 \mathrm{H}_{2} \mathrm{O}, \mathrm{NaOH}$, and ethanol were purchased from Sinopharm Chemical Reagent Co., Ltd, China. All reagents were used without further purification. Hydrogen gas and ethylene were from Dalian Guangming Gas Co., China. The reaction gas ( $0.80 \%$ methane, $0.50 \%$ acetylene, and $98.70 \%$ ethylene) and the treatment gas of $0.50 \%$ acetylene in argon were provided by Dalian Guangming Gas Co., China.

4.2. Preparation of Catalysts. As the precursor, $\mathrm{Cu}$ $(\mathrm{OH})_{2}$ was synthesized as follows. $50 \mathrm{~mL}$ of $\mathrm{NaOH}$ aqueous solution $(2.0 \mathrm{~mol} / \mathrm{L})$ was added dropwise into $200 \mathrm{~mL}$ of $\mathrm{Cu}\left(\mathrm{NO}_{3}\right)_{2}$ aqueous solution $(0.1 \mathrm{~mol} / \mathrm{L})$ at $0{ }^{\circ} \mathrm{C}$ and stirred for $30 \mathrm{~min}$. The blue $\mathrm{Cu}(\mathrm{OH})_{2}$ precipitate was collected by 
suction filtration, washed with deionized water and ethanol, and then dried at $30{ }^{\circ} \mathrm{C}$ in a vacuum oven for $12 \mathrm{~h}$. The acetylene hydrogenation catalyst was prepared in situ from $\mathrm{Cu}(\mathrm{OH})_{2}$ by thermal treatment with acetylene-containing gas followed by hydrogen reduction, prior to the selective hydrogenation.

In order to investigate the formation of copper carbide, copper (II) acetylide $\left(\mathrm{CuC}_{2}\right)$ was synthesized as reported in the literature. ${ }^{43} 1.21 \mathrm{~g}$ of $\mathrm{Cu}\left(\mathrm{NO}_{3}\right)_{2} \cdot 3 \mathrm{H}_{2} \mathrm{O}$ was dissolved in a $5.0 \%$ ammonia solution $(100 \mathrm{~mL})$. Ar flow $(50 \mathrm{~mL} / \mathrm{min})$ was bubbled through the solution for $30 \mathrm{~min}$ and then shifted to a mixture gas $\left(10.0 \% \mathrm{C}_{2} \mathrm{H}_{2}\right.$ and $\left.90.0 \% \mathrm{Ar}\right)$ regulated by two separate mass flow meters. After $5 \mathrm{~h}$, the dark precipitate $\left(\mathrm{CuC}_{2}\right)$ was collected through centrifugation and then washed with deionized water and ethanol and kept in water. (CAUTION: Dry $\mathrm{CuC}_{2}$ is highly explosive.)

When $\mathrm{CuC}_{2}$ was used as the precursor, a wet sample was carefully loaded in the quartz tubular reactor, which was heated in a hydrogen flow $(50 \mathrm{~mL} / \mathrm{min})$ from room temperature to $150{ }^{\circ} \mathrm{C}$ at $3{ }^{\circ} \mathrm{C} / \mathrm{min}$ and kept for $3 \mathrm{~h}$. The obtained catalyst is denoted as $\mathrm{CuC}_{2} @ 150-\mathrm{H}_{2}$. In comparison, the wet $\mathrm{CuC}_{2}$ sample was annealed at $150{ }^{\circ} \mathrm{C}$ for $3 \mathrm{~h}$ in vacuum, and the resultant material is denoted as $\mathrm{CuC}_{2} @ 150$-vacuum. Both the obtained samples were nonexplosive and stable in air.

4.3. Catalyst Characterization. SEM observation was conducted on a SU8220 instrument with a beam energy of 5.0 $\mathrm{kV}$. Powder XRD measurement was performed on a Rigaku SmartLab diffractometer with $\mathrm{Cu} \mathrm{K} \alpha$ radiation at $40 \mathrm{kV}$ and $100 \mathrm{~mA}$ with a scanning rate of $8^{\circ} / \mathrm{min}$ between 20 and $80^{\circ}$. TEM observation was performed on a FEI Tecnai G2 F30 instrument which was operated at $300 \mathrm{kV}$. The data of XPS was collected on a Thermo Fisher ESCALAB Xi ${ }^{+}$electron spectrometer equipped with a monochromatic $\mathrm{Al} \mathrm{K} \alpha$ excitation source $(h \nu=1486.6 \mathrm{eV})$. All binding energies were referenced to the $\mathrm{C}$ 1s peak $(284.6 \mathrm{eV})$. Raman spectrum was recorded using a Thermo Scientific DXR Raman instrument with a 532 $\mathrm{nm}$ laser beam as the excitation source. Nitrogen sorption isotherms were measured at $-196{ }^{\circ} \mathrm{C}$ on a Micromeritics TriStar II 3020 instrument. The specific surface areas were calculated according to the BET method. TG-DSC measurement was carried out on a TGA Q50 instrument in $\mathrm{N}_{2}$ flow $(50 \mathrm{~mL} / \mathrm{min})$, and the heating rate was $3{ }^{\circ} \mathrm{C} / \mathrm{min}$.

4.4. Catalytic Performance. The selective hydrogenation of acetylene in an ethylene stream was performed at ambient pressure in a quartz tubular fixed-bed reactor $(10 \mathrm{~mm}$ i.d.). The synthesized $\mathrm{Cu}(\mathrm{OH})_{2}(0.1 \mathrm{~g})$ was mixed with quartz sands (0.6 g, 60-80 mesh) and sandwiched in the middle of the reactor by quartz sands. The reactor was heated in the treatment gas $\left(0.50 \% \mathrm{C}_{2} \mathrm{H}_{2}\right.$ and $99.50 \% \mathrm{Ar}$, at $\left.30 \mathrm{~mL} / \mathrm{min}\right)$ from room temperature to a set temperature $\left(100-140{ }^{\circ} \mathrm{C}\right)$ at $3{ }^{\circ} \mathrm{C} / \mathrm{min}$ and kept for $2 \mathrm{~h}$ and then cooled down to room temperature. The obtained material was denoted as $\mathrm{Cu}$ $(\mathrm{OH})_{2}(\mathrm{~T} x)$ ( $x$ represents the temperature of the thermal treatment). At a low $\mathrm{C}_{2} \mathrm{H}_{2}$ concentration, no vigorous or explosive decomposition was observed. Then, $\mathrm{Cu}(\mathrm{OH})_{2}(\mathrm{~T} x)$ was heated in a hydrogen flow $\left(50 \mathrm{~mL} / \mathrm{min}_{2}\right)$ from room temperature to a set temperature $\left(130-210{ }^{\circ} \mathrm{C}\right)$ at $3{ }^{\circ} \mathrm{C} / \mathrm{min}$ and kept for $3 \mathrm{~h}$ and then cooled down to room temperature. The obtained catalyst is denoted as $\mathrm{Cu}(\mathrm{OH})_{2}(\mathrm{~T} x-\mathrm{R} y)(y$ stands for the reduction temperature $). \mathrm{Cu}(\mathrm{OH})_{2}(\mathrm{~T} x-\mathrm{R} y)$ was stable (not explosive) at high temperatures or on exposure to air. For comparison, a metal $\mathrm{Cu}$ catalyst was obtained by reducing $\mathrm{Cu}(\mathrm{OH})_{2}$ in $\mathrm{H}_{2}(50 \mathrm{~mL} / \mathrm{min})$ at $400{ }^{\circ} \mathrm{C}$ for $5 \mathrm{~h}$.
In the selective hydrogenation of acetylene, a mixture gas (90.0\% reaction gas and $10.0 \% \mathrm{H}_{2}$ ) was fed at $10 \mathrm{~mL} / \mathrm{min}$, and the reactor was heated from room temperature to the reaction temperature $\left(90-120{ }^{\circ} \mathrm{C}\right)$ at $3{ }^{\circ} \mathrm{C} / \mathrm{min}$. The gas composition at the reactor outlet was determined by an online gas chromatograph (GC A90, ECHROM) equipped with a flame ionization detector and a capillary column (Agilent HP-AL/S, $30 \mathrm{~m} \times 0.535 \mathrm{~mm} \times 15.00 \mu \mathrm{m})$. Methane was used as the internal standard for the gas chromatography (GC) analysis. Because it is difficult to accurately measure the concentration increment of ethylene by GC at a concentration as high as $98.7 \%$, the selectivity to ethane was used to determine the selectivity performance of the catalyst. Acetylene conversion and ethane selectivity were calculated as follows. ${ }^{44}$

$$
\begin{aligned}
& \mathrm{C}_{2} \mathrm{H}_{2} \text { conversion }(\%)=\frac{\left[\mathrm{C}_{2} \mathrm{H}_{2}\right]_{\text {inlet }}-\left[\mathrm{C}_{2} \mathrm{H}_{2}\right]_{\text {outlet }}}{\left[\mathrm{C}_{2} \mathrm{H}_{2}\right]_{\text {inlet }}} \times 100 \\
& \mathrm{C}_{2} \mathrm{H}_{6} \text { selectivity }(\%)=\frac{\left[\mathrm{C}_{2} \mathrm{H}_{6}\right]_{\text {outlet }}}{\left[\mathrm{C}_{2} \mathrm{H}_{2}\right]_{\text {inlet }}-\left[\mathrm{C}_{2} \mathrm{H}_{2}\right]_{\text {outlet }}} \times 100
\end{aligned}
$$

where $\left[\mathrm{C}_{2} \mathrm{H}_{2}\right]_{\text {inlet }}$ and $\left[\mathrm{C}_{2} \mathrm{H}_{2}\right]_{\text {outlet }}$ are the acetylene concentrations at the inlet and at the outlet, respectively; $\left[\mathrm{C}_{2} \mathrm{H}_{6}\right]_{\text {outlet }}$ is the ethane concentration at the outlet.

\section{ASSOCIATED CONTENT}

\section{Supporting Information}

The Supporting Information is available free of charge at https://pubs.acs.org/doi/10.1021/acsomega.0c05759.

Raman spectra of $\mathrm{Cu}(\mathrm{OH})_{2}(\mathrm{~T} 120)$ and $\mathrm{Cu}$ $(\mathrm{OH})_{2}(\mathrm{~T} 120-\mathrm{R} 150) ; \mathrm{N}_{2}$ adsorption-desorption isotherms and specific surface areas of $\mathrm{Cu}(\mathrm{OH})_{2}, \mathrm{Cu}$ $(\mathrm{OH})_{2}(\mathrm{~T} 120), \mathrm{Cu}(\mathrm{OH})_{2}(\mathrm{~T} 120-\mathrm{R} 150), \mathrm{CuC}_{2} @ 150-\mathrm{H}_{2}$, and $\mathrm{CuC}_{2} @ 150$-vacuum; XPS spectra of $\mathrm{CuC}_{2} @ 150$ $\mathrm{H}_{2}$; and TG-DSC curve of $\mathrm{CuC}_{2}$ (PDF)

\section{AUTHOR INFORMATION}

\section{Corresponding Authors}

Yao Wang - State Key Laboratory of Fine Chemicals, School of Chemical Engineering, Dalian University of Technology, Dalian 116024, P. R. China; Liaoning Key Laboratory of Petrochemical Technology and Equipment, Dalian University of Technology, Dalian 116024, P. R. China;

Email: wangyao@dlut.edu.cn

Anjie Wang - State Key Laboratory of Fine Chemicals, School of Chemical Engineering, Dalian University of Technology, Dalian 116024, P. R. China; Liaoning Key Laboratory of Petrochemical Technology and Equipment, Dalian University of Technology, Dalian 116024, P. R. China; (1) orcid.org/ 0000-0001-7816-6981; Email: ajwang@dlut.edu.cn

\section{Authors}

Chenyang Lu - State Key Laboratory of Fine Chemicals, School of Chemical Engineering, Dalian University of Technology, Dalian 116024, P. R. China

Aonan Zeng - State Key Laboratory of Fine Chemicals, School of Chemical Engineering, Dalian University of Technology, Dalian 116024, P. R. China

Complete contact information is available at: https://pubs.acs.org/10.1021/acsomega.0c05759 


\section{Notes}

The authors declare no competing financial interest.

\section{ACKNOWLEDGMENTS}

The work is supported by the Natural Science Foundation of China (21972014, 21473017, and U1508205), the Fundamental Research Funds for the Central Universities (DUT19GJ205), and International S\&T Cooperation Program of China (2016YFE0109800).

\section{REFERENCES}

(1) Kim, W.-J.; Moon, S. H. Modified Pd Catalysts for the Selective Hydrogenation of Acetylene. Catal. Today 2012, 185, 2-16.

(2) Takht Ravanchi, M.; Sahebdelfar, S.; Komeili, S. Acetylene Selective Hydrogenation: A Technical Review On Catalytic Aspects. Rev. Chem. Eng. 2018, 34, 215-237.

(3) Molnár, A.; Sárkány, A.; Varga, M. Hydrogenation of Carbon Carbon Multiple Bonds: Chemo-, Regio- And Stereo-Selectivity. J. Mol. Catal. A: Chem. 2001, 173, 185-221.

(4) Huang, W.; McCormick, J.; Lobo, R.; Chen, J. Selective Hydrogenation of Acetylene in the Presence of Ethylene on ZeoliteSupported Bimetallic Catalysts. J. Catal. 2007, 246, 40-51.

(5) Borodziński, A.; Bond, G. C. Selective Hydrogenation of Ethyne in Ethene - Rich Streams on Palladium Catalysts. Part 1. Effect of Changes to the Catalyst During Reaction. Catal. Rev. 2006, 48, 91144.

(6) Nikolaev, S. A.; Zanaveskin, L. N.; Smirnov, V. V.; Averyanov, V. A.; Zanaveskin, K. L. Catalytic Hydrogenation of Alkyne and Alkadiene Impurities in Alkenes. Practical and Theoretical Aspects. Russ. Chem. Rev. 2009, 78, 231-247.

(7) Jin, Y.; Datye, A. K.; Rightor, E.; Gulotty, R.; Waterman, W.; Smith, M.; Holbrook, M.; Maj, J.; Blackson, J. The Influence of Catalyst Restructuring on the Selective Hydrogenation of Acetylene to Ethylene. J. Catal. 2001, 203, 292-306.

(8) Kim, W. Deactivation Behavior of a $\mathrm{TiO}_{2}$-Added Pd Catalyst in Acetylene Hydrogenation. J. Catal. 2004, 226, 226-229.

(9) Zea, H.; Lester, K.; Datye, A. K.; Rightor, E.; Gulotty, R.; Waterman, W.; Smith, M. The Influence of Pd-Ag Catalyst Restructuring on the Activation Energy for Ethylene Hydrogenation in Ethylene-Acetylene Mixtures. Appl. Catal., A 2005, 282, 237-245.

(10) Kuhn, M.; Lucas, M.; Claus, P. Long-Time Stability vs Deactivation of Pd-Ag/ $\mathrm{Al}_{2} \mathrm{O}_{3}$ Egg-Shell Catalysts in Selective Hydrogenation of Acetylene. Ind. Eng. Chem. Res. 2015, 54, 66836691.

(11) He, Y.; Liu, Y.; Yang, P.; Du, Y.; Feng, J.; Cao, X.; Yang, J.; Li, D. Fabrication of a PdAg Mesocrystal Catalyst for the Partial Hydrogenation of Acetylene. J. Catal. 2015, 330, 61-70.

(12) Zhang, Q.; Li, J.; Liu, X.; Zhu, Q. Synergetic Effect of Pd and $\mathrm{Ag}$ Dispersed on $\mathrm{Al}_{2} \mathrm{O}_{3}$ in the Selective Hydrogenation of Acetylene. Appl. Catal., A 2000, 197, 221-228.

(13) Hu, M.; Yang, W.; Liu, S.; Zhu, W.; Li, Y.; Hu, B.; Chen, Z.; Shen, R.; Cheong, W.-C.; Wang, Y.; Zhou, K.; Peng, Q.; Chen, C.; Li, Y. Topological Self-Template Directed Synthesis of Multi-Shelled Intermetallic $\mathrm{Ni}_{3} \mathrm{Ga}$ Hollow Microspheres for the Selective Hydrogenation of Alkyne. Chem. Sci. 2019, 10, 614-619.

(14) Chai, Y.; Wu, G.; Liu, X.; Ren, Y.; Dai, W.; Wang, C.; Xie, Z.; Guan, N.; Li, L. Acetylene-Selective Hydrogenation Catalyzed by Cationic Nickel Confined in Zeolite. J. Am. Chem. Soc. 2019, 141, 9920-9927.

(15) Liu, Y.; Zhao, J.; Feng, J.; He, Y.; Du, Y.; Li, D. Layered Double Hydroxide-Derived Ni-Cu Nanoalloy Catalysts for Semi-Hydrogenation of Alkynes: Improvement of Selectivity and Anti-Coking Ability via Alloying of $\mathrm{Ni}$ and $\mathrm{Cu}$. J. Catal. 2018, 359, 251-260.

(16) Spanjers, C. S.; Held, J. T.; Jones, M. J.; Stanley, D. D.; Sim, R. S.; Janik, M. J.; Rioux, R. M. Zinc Inclusion to Heterogeneous Nickel Catalysts Reduces Oligomerization During the Semi-Hydrogenation of Acetylene. J. Catal. 2014, 316, 164-173.
(17) Studt, F.; Abild-Pedersen, F.; Bligaard, T.; Sorensen, R. Z.; Christensen, C. H.; Norskov, J. K. Identification of Non-Precious Metal Alloy Catalysts for Selective Hydrogenation of Acetylene. Science 2008, 320, 1320-1322.

(18) Abello, S.; Verboekend, D.; Bridier, B.; Perezramirez, J. Activated Takovite Catalysts for Partial Hydrogenation of Ethyne, Propyne, and Propadiene. J. Catal. 2008, 259, 85-95.

(19) Liu, Y.; Liu, X.; Feng, Q.; He, D.; Zhang, L.; Lian, C.; Shen, R.; Zhao, G.; Ji, Y.; Wang, D.; Zhou, G.; Li, Y. Intermetallic $\mathrm{Ni}_{\mathrm{x}} \mathrm{M}_{\mathrm{y}}(\mathrm{M}=$ Ga and Sn) Nanocrystals: A Non-Precious Metal Catalyst for SemiHydrogenation of Alkynes. Adv. Mater. 2016, 28, 4747-4754.

(20) Shi, X.; Lin, Y.; Huang, L.; Sun, Z.; Yang, Y.; Zhou, X.; Vovk, E.; Liu, X.; Huang, X.; Sun, M.; Wei, S.; Lu, J. Copper Catalysts in Semihydrogenation of Acetylene: From Single Atoms to Nanoparticles. ACS Catal. 2020, 10, 3495-3504.

(21) Huang, F.; Deng, Y.; Chen, Y.; Cai, X.; Peng, M.; Jia, Z.; Xie, J.; Xiao, D.; Wen, X.; Wang, N.; Jiang, Z.; Liu, H.; Ma, D. Anchoring $\mathrm{Cu}_{1}$ Species over Nanodiamond-Graphene for Semi-Hydrogenation of Acetylene. Nat. Commun. 2019, 10, 4431.

(22) Bridier, B.; Pérez-Ramírez, J. Cooperative Effects in Ternary $\mathrm{Cu}-\mathrm{Ni}-\mathrm{Fe}$ Catalysts Lead to Enhanced Alkene Selectivity in Alkyne Hydrogenation. J. Am. Chem. Soc. 2010, 132, 4321-4327.

(23) Bridier, B.; Hevia, M. A. G.; López, N.; Pérez-Ramírez, J. Permanent Alkene Selectivity Enhancement in Copper-Catalyzed Propyne Hydrogenation by Temporary CO Supply. J. Catal. 2011, 278, 167-172.

(24) Bridier, B.; López, N.; Pérez-Ramírez, J. Partial Hydrogenation of Propyne over Copper-Based Catalysts and Comparison with Nickel-Based Analogues. J. Catal. 2010, 269, 80-92.

(25) Tejeda-Serrano, M.; Mon, M.; Ross, B.; Gonell, F.; FerrandoSoria, J.; Corma, A.; Leyva-Pérez, A.; Armentano, D.; Pardo, E. Isolated $\mathrm{Fe}(\mathrm{III})-\mathrm{O}$ Sites Catalyze the Hydrogenation of Acetylene in Ethylene Flows under Front-End Industrial Conditions. J. Am. Chem. Soc. 2018, 140, 8827-8832.

(26) Armbrüster, M.; Kovnir, K.; Friedrich, M.; Teschner, D.; Wowsnick, G.; Hahne, M.; Gille, P.; Szentmiklósi, L.; Feuerbacher, M.; Heggen, M.; Girgsdies, F.; Rosenthal, D.; Schlögl, R.; Grin, Y. $\mathrm{Al}_{13} \mathrm{Fe}_{4}$ as a Low-Cost Alternative for Palladium in Heterogeneous Hydrogenation. Nat. Mater. 2012, 11, 690-693.

(27) Zhao, Z. J.; Zhao, J.; Chang, X.; Zha, S.; Zeng, L.; Gong, J. Competition of $\mathrm{C}-\mathrm{C}$ Bond Formation and $\mathrm{C}-\mathrm{H}$ Bond Formation for Acetylene Hydrogenation on Transition Metals: A Density Functional Theory Study. AIChE J. 2019, 65, 1059-1066.

(28) Zhang, R.; Zhao, B.; Ling, L.; Wang, A.; Russell, C. K.; Wang, B.; Fan, M. Cost-Effective Palladium-Doped Cu Bimetallic Materials to Tune Selectivity and Activity by Using Doped Atom Ensembles as Active Sites for Efficient Removal of Acetylene from Ethylene. ChemCatChem 2018, 10, 2424-2432.

(29) Bridier, B.; López, N.; Pérez-Ramírez, J. Molecular Understanding of Alkyne Hydrogenation for the Design of Selective Catalysts. Dalton Trans. 2010, 39, 8412-8419.

(30) Stammbach, M. R.; Thomas, D. J.; Trimm, D. L.; Wainwright, M. S. Hydrogenation of Ethyne Over an Ion-Exchanged Copper On Silica Catalyst. Appl. Catal. 1990, 58, 209-217.

(31) Kyriakou, G.; Boucher, M. B.; Jewell, A. D.; Lewis, E. A.; Lawton, T. J.; Baber, A. E.; Tierney, H. L.; Flytzani-Stephanopoulos, M.; Sykes, E. C. H. Isolated Metal Atom Geometries as a Strategy for Selective Heterogeneous Hydrogenations. Science 2012, 335, 12091212.

(32) McCue, A. J.; McRitchie, C. J.; Shepherd, A. M.; Anderson, J. A. $\mathrm{Cu} / \mathrm{Al}_{2} \mathrm{O}_{3}$ Catalysts Modified with $\mathrm{Pd}$ for Selective Acetylene Hydrogenation. J. Catal. 2014, 319, 127-135.

(33) Lu, C.; Wang, Y.; Zhang, R.; Wang, B.; Wang, A. Preparation of an Unsupported Copper-Based Catalyst for Selective Hydrogenation of Acetylene from $\mathrm{Cu}_{2} \mathrm{O}$ Nanocubes. ACS Appl. Mater. Interfaces 2020, 12, 46027.

(34) Bao, H.; Zhang, W.; Hua, Q.; Jiang, Z.; Yang, J.; Huang, W. Crystal-Plane-Controlled Surface Restructuring and Catalytic Per- 
formance of Oxide Nanocrystals. Angew. Chem., Int. Ed. 2011, 50, 12294-12298.

(35) Tian, J.; Liu, Q.; Cheng, N.; Asiri, A. M.; Sun, X. SelfSupported $\mathrm{Cu}_{3} \mathrm{P}$ Nanowire Arrays as an Integrated High-Performance Three-Dimensional Cathode for Generating Hydrogen from Water. Angew. Chem., Int. Ed. 2014, 53, 9577-9581.

(36) Fox, E. B.; Velu, S.; Engelhard, M. H.; Chin, Y.-H.; Miller, J. T.; Kropf, J.; Song, C. Characterization of $\mathrm{CeO}_{2}$-Supported Cu-Pd Bimetallic Catalyst for the Oxygen-Assisted Water-Gas Shift Reaction. J. Catal. 2008, 260, 358-370.

(37) Martí.N, M. T.; Callejas, M. A.; Benito, A. M.; Cochet, M.; Seeger, T.; Ansón, A.; Schreiber, J.; Gordon, C.; Marhic, C.; Chauvet, O.; Fierro, J. L. G.; Maser, W. K. Sensitivity of Single Wall Carbon Nanotubes to Oxidative Processing: Structural Modification, Intercalation and Functionalisation. Carbon 2003, 41, 2247-2256.

(38) Perret, N.; Wang, X.; Delannoy, L.; Potvin, C.; Louis, C.; Keane, M. A. Enhanced Selective Nitroarene Hydrogenation over Au Supported on $\beta-\mathrm{Mo}_{2} \mathrm{C}$ and $\beta-\mathrm{Mo}_{2} \mathrm{C} / \mathrm{Al}_{2} \mathrm{O}_{3}$. J. Catal. 2012, 286, 172183.

(39) Kim, S. W.; Son, Y.; Choi, K.; Kim, S. I.; Son, Y.; Park, J.; Lee, J. H.; Jang, J. H. Highly Active Bifunctional Electrocatalysts for Oxygen Evolution and Reduction in Zn-Air Batteries. ChemSusChem 2018, 11, $4203-4208$.

(40) Hodge, S. A.; Bayazit, M. K.; Tay, H. H.; Shaffer, M. S. P. Giant Cationic Polyelectrolytes Generated via Electrochemical Oxidation of Single-Walled Carbon Nanotubes. Nat. Commun. 2013, 4, 1989.

(41) Brameld, V. F.; Clark, M. T.; Seyfang, A. P. Copper Acetylides. J. Indian Chem. Soc. 1947, 66, 346-353.

(42) Miller, S. A.; Penny, E. Proceedings of the Symposium on Chemical Process Hazards; Institution of Chemical Engineers: London, Manchester, 1960.

(43) Patnaik, P. Handbook of Inorganic Chemicals; McGraw-Hill: New York, 2002; pp 258-260.

(44) Pei, G. X.; Liu, X. Y.; Wang, A.; Lee, A. F.; Isaacs, M. A.; Li, L.; Pan, X.; Yang, X.; Wang, X.; Tai, Z.; Wilson, K.; Zhang, T. Ag Alloyed Pd Single-Atom Catalysts for Efficient Selective Hydrogenation of Acetylene to Ethylene in Excess Ethylene. ACS Catal. 2015, 5, 37173725. 